\title{
A leap into controversy
}

\section{Washington}

A CALIFORNIA-BASED television scriptwriter has found himself at the centre of a bitter row between biomedical research advocates and animal rights activists, who have learned of his plan to feature a chimpanzee involved in a head injury research project as the central character in an episode of a popular US television series.

Paul Brown writes for the NBCnetworked show Quantum Leap, in which the hero is a scientist of the future who transports himself into the bodies of characters from other times. Previously, the show has used this format to explore controversial issues such as racial discrimination. But the storm whipped up by a report in the national television listings magazine TV Guide about Brown's plan to have the character appear in the body of a research chimpanzee has surpassed anything the show's executives have experienced before.

That report quoted Deborah Pratt, co-executive producer of Quantum Leap, as saying "the animal rights people are in heaven," and has prompted a furious letter-writing campaign by the California Biomedical Research Association and a host of individual researchers. "It appears that in the development of this episode, the lies and misrepresentations of the animal rights movement have been accepted," says one letter to Quantum Leap's producers, from David Ramsay, the University of California, San Francisco. Sandra Bressler of the California Biomedical Research Association argues that script should perhaps include a head injury patient helped by results from the BIOMEDICAL RESEARCH

\section{New institute snares prize team}

\section{Washington}

A NEWLY established biomedical research institute in Long Island, New York, has made a good start by luring a leading research team from Rockefeller University in New York City. Anthony Cerami, whose work has centred on cytokines and on diabetes, and 13 of his colleagues will begin work later this summer at the Picower Institute at Long Island's North Shore University Hospital.

The institute has been given an initial endowment of $\mathbf{\$ 1 0}$ million by the financier Jeffrey Picower and his wife Barbara, but Cerami says he expects this to grow tenfold over the next five years, allowing the institute to house some 100 researchers and to rival in size such established centres as the Whitehead Institute in Cambridge, Massachusetts.

Approximately 80 per cent of the new research project.

Animal rights groups respond that Bressler and her allies, by putting pressure on the show's producers, are attempting to suppress free speech. Shirley McGreal from the International Primate Protection League says she fears that the pressure being applied by the biomedical research lobby will result in the programme being cancelled.

The script, set in 1972, involves a chimpanzee used for language research, which is then transferred to a project investigating head injuries. The chimpanzee receives a number of blows to the head and is killed, after which the project leader discovers that the chimpanzee is not an appropriate model to study head injuries in humans.

Brown's idea is based loosely on a head injury research project described in the Journal of Neurosurgery $(39,152 ; 1973)$. Ayub Ommaya, the principal investigator on that project, says the chimpanzee work was a one-time experiment to check that work with smaller laboratory animal models could be scaled up to apply to human head injuries. The project yielded data that were used to develop restraints to minimize head injuries in road accidents, he says.

Brown's characterization of a similar research project as being unnecessary annoys Bressler. "I appreciate artistic license, but . . . when you're dealing with an issue of such significant controversy, you have some obligation not to misrepresent it to one side or the other." But Brown is unperturbed by criticism of his script. "Good television will always stir up controversy."

Peter Aldhous

institute's work, Cerami says, will be research into diseases associated with ageing.

Cerami's departure from Rockefeller has attracted considerable publicity because he was prominent among a faction of the Rockefeller faculty that two years ago argued against the appointment David Baltimore as Rockefeller president. Cerami feared that Baltimore's association with the controversy surrounding the alleged fabrication of data by Thereza Imanishi-Kari in a disputed 1986 Cell paper would undermine his ability to serve as Rockefeller's president. But Cerami says his decision to leave the university was influenced by the unique opportunity given by the Picowers' offer, rather than by Baltimore's presence at Rockefeller. "I would have left no matter who was president."

Peter Aldhous

\section{Fullerenes heat up}

\section{Washington}

A research team led by Ray Baughman and Zafar Iqbal, from Allied Signal's laboratories in New Jersey, last week announced that they have produced a superconducting doped fullerene with a transition temperature around $42 \mathrm{~K}$. The finding, revealed at a meeting in Philadelphia, exceeds the previous highest temperature claimed for fullerene superconductivity by some $10 \mathrm{~K}$. The compound is doped with rubidium and thallium, and Baughman says that adding thallium to both rubidium- and potassium-doped fullerene seems to raise the transition temperature by several degrees. Rick Smalley, a leading fullerene researcher from Rice University in Houston says, "The consensus of people at the meeting was that it is a very impressive result, and probably real".

P.A.

\section{Switchboard in orbit}

AFTER the usual series of false starts, the US space shuttle Atlantis carried a Tracking Data Relay Satellite (TDRS) into orbit last Friday, 2 August. The TDRS network of geostationary satellites is vital for communication between US space science satellites and National Aeronautics and Space Administration (NASA) ground stations - each satellite acts as an orbiting communications 'switchboard', relaying data from missions such as the Hubble Space Telescope and the Gamma Ray Observatory back to Earth.

Until last week, NASA had three of these satellites in orbit. But two of the three are not working properly, and are being run together to mimic a fully functional TDRS. With one of these satellites nearing the end of its expected life, last week's TDRS launch was a high priority, to ensure good data communications for NASA's planned science missions.

P.A

\section{Space exchange}

THE improved relations between the United States and the Soviet Union will soon be reflected in the first US-Soviet cooperation in manned spaceflight since the symbolic docking between Apollo and Soyuz capsules in 1975. During their meeting in Moscow last week, Presidents George Bush and Mikhail Gorbachev agreed to send a US astronaut to the Soviet Mir space station for several months, and for a Soviet cosmonaut to fly on a future space shuttle mission.

The missions are expected to concentrate on life sciences and medical research - now the chief scientific justification for the $\$ 30,000$-million-plus space station Freedom project. A priority will be standardizing the different measurements used to monitor the health of astronauts under weightless conditions.

P.A. 